\title{
Synthesis of Trimethylolpropane Esters of Calophyllum Methyl Esters: Effect of Temperature and Molar Ratio
}

\author{
Yeti Widyawati1a, Ani Suryani2a, Muhammad Romli2b and Sukardi²c \\ 1) Department of Chemical Engineering, Faculty of Technology Industry, University Jayabaya, Jakarta, Indonesia \\ 2a,b,c)Department of Agroindustrial Technology, Faculty of Agriculture Engineering and Technology, Bogor Agricultural University, Bogor, Indonesia
}

\begin{abstract}
Trimethylolpropane esters were synthesized by transesterification of calophyllum methyl esters and trimethylolpropane using a calcium oxide as the catalyst. The results showed that the optimal reaction conditions (temperature: $130{ }^{\circ} \mathrm{C}$, reaction time: $5 \mathrm{~h}$, reactant molar ratio: $3.9: 1$, catalyst amount $3 \% \mathrm{w} / \mathrm{w}$, and formed trimethylolpropane ester of $79.0 \%$ were obtained. The basic physicochemical properties of the trimethylolpropane esters were the following : kinematic viscosities of $56.40 \mathrm{cSt}$ and $8.8 \mathrm{cSt}$ at $40^{\circ} \mathrm{C}$ and $100^{\circ} \mathrm{C}$, viscosity index 193 , flash point $218{ }^{\circ} \mathrm{C}$ and pour point $-3^{\circ} \mathrm{C}$. So Methyl esters of fatty acids of would callophylum methyl ester is good raw material for the synthesis of lubricating oils.
\end{abstract}

Keywords: callophylum methyl ester, transesterification, calcium oxide, trimethylolpropane esters.

Article History: Received March 12, 2014; Received in revised form July 23, 2014; Accepted August 10, 2014; Available online

How to Cite This Article: Widyawati,Y., Suryani, A., Romli,M. \& Sukardi (2014) Synthesis of Trimethylolpropane Esters of Calophyllum Methyl Esters : Effect of Temperature and Molar Ratio. Int. Journal of Renewable Energy Development, 3(3), 188-192.

http://dx.doi.org/10.14710/ijred.3.3.188-192

\section{Introduction}

These last few years, the environmental issues and austerity of fossil raw materials require the development of environmentally friendly lubricants. Mineral oil-based lubricants are classified as nonrenewable and environmentally-unfriendly materials (Salimon et al. 2010). In order to meet the demands of environmentally friendly lubricants and to use modern machines, it must be developed a synthetic lubricants.

Esters of vegetable oils are one of the recommended materials to be developed into a lubricant (Willing. 2001). Some vegetable oils used to make a synthetic lubricants are sunflower seed oil, castor, palm, rapeseed and soybean (Lathi PS \& Mattiason 2007; Gryglewics et al. 2003). On the other hand, vegetable oil is environmentally friendly, because it is a renewable natural resource and can be degraded biologically.

There are several reasons to use vegetable oils or vegetable oil derivatives as biolubricants. Because as much as $40 \%$ (Castro et al. 2006) of a lubricant can be lost to the environment, the inherent biodegradability of vegetable oils reduces their environmental impact. Other advantages include low volatility, superior lubricity and good anticorrosion properties (Doll et al. 2007; Metzger 2009).

However, vegetable oils also have the poor properties such as having a low oxidation stability and high pour point, both of which are critical factors for lubricants. The low oxidation resistance is caused by the carbon-carbon double bonds in the fatty acid chain and beta hydrogen on glycerol susceptible to oxygen assault. If there are two or more double bonds (polyunsaturated), the more easily oxidized. Meanwhile the presence of betta hydrogen will facilitate the breakup of triglycerides into acid and olefin. Transesterification is defined as the reaction (Leung et al. 2010) in which a triglyceride molecule reacts with three moles of methanol to result in glycerol and mixtures of fatty acid methyl esters. The transesterification of vegetable oil-derived methyl 
Citation: Widyawati,Y., Suryani, A., Romli,M. \& Sukardi (2014) Synthesis of Trimethylolpropane Esters of Calophyllum Methyl Esters : Effect of Temperature and Molar Ratio. Int. Journal of Renewable Energy Development, 3(3), 188-192. doi: 10.14710/ijred.3.3.188-192

$\mathrm{P}$ a g e 189

esters with polyols is essentially the reverse of the transesterification reaction, in which glycerol is replaced by a commercial polyol. The most significant advantage of using a polyol instead of glycerol is that the absence of betta hydrogens enhances the thermal stability of the lubricant at high temperatures by preventing self polymerization to form free fatty acids (Leung et al. 2010). Figure 1 show the chemical reaction between calophyllum methyl esters (CMEs) and trimethylolpropane (TMP).

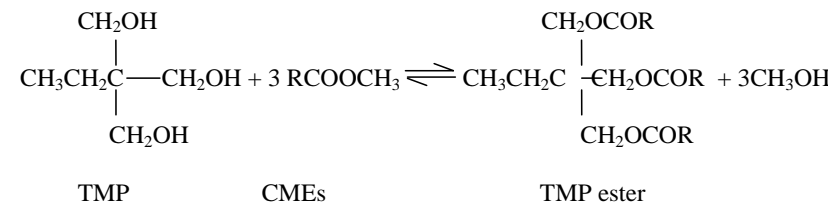

Fig. 1 reaction of TMP with CMEs

Previous studies reported on transesterification of palm oil methyl ester (POME) and palm kernel oil (PKO) with trimethylolpropane (TMP), which has been successfully converted into triesters of $98 \%$ (Yunus 2003). Another study work reported using trimethylolpropane (TMP) and neopentylglycol (NPG) as a polyol with some vegetable oils such as olive oil, rapeseed oil and lard (Campanella et al. 2010). Uosukainen et al. (1998) describe the synthesis of trimethylolpropane esters of rapeseed oil methyl ester (ROME) using sodium methylate catalyst $(0.5 \% \mathrm{w} / \mathrm{w})$ were added to the reaction mixture. The reaction mixture is passed under pressure of $3.3 \mathrm{kPa}$ for 8 hours. The effects of pressure, the molar ratio (TMP: ROME), reaction time, and reaction temperature investigated. The production of canola oil-based lubricant was studied transesterification with trimethylolpropane (TMP) using sodium methoxide as catalyst. They found the reaction conditions to obtain maximum yield of TMP trioleate. Canola derived biolubricant with TMP triester composition of $90.9 \%$ was obtained after $5 \mathrm{~h}$ (Sripada et al. 2013).

In the present study, calophyllum methyl esters is used to produce TMP esters. Calophyllum oil is semidried oil, rich in unsaturated fatty acids (oleic, lenoleic and lenolenic) which form $69.46 \%$ of total fatty acid composition of the oil. Presently, many studies on calophyllum oil shown that it has many potential for industrial application such as methyl esters. The objective of this study is to optimized the transesterification of calophyllum methyl esters with TMP to achieve the maximum production of TE. Through this process, TMP ester which is formed can be used as a basic material in the lubricant production.

\section{Materials and Methods}

\subsection{Materials}

Calophyllum methyl esters (CMEs), 2-ehtyl-2(hydroxymethyl)- 1,3-propanediol and calcium oxide, was purchased from Merck Schuchardt. Other chemicals such as ethyl acetate and N, O-Bis (trimethylsilyl) trifluoroacetamide (BSTFA) were purchased from Sigma Aldrich.

\subsection{Fractionation}

Approximately $50 \%$ of the original calophyllum methyl esters (CMEs) were fractionated via vacuum distillation at temperatures of $170-180{ }^{\circ} \mathrm{C}$ under vacuum pressures of 2 mbar. The bottom product, which contains CMEs, was dried overnight in an oven at $110{ }^{\circ} \mathrm{C}$ to decrease the moisture content, and $200 \mathrm{~g}$ of it was used as the starting material in the synthesis of high oleic calophyllum oil based trimethylolpropane esters.

\subsection{Transesterification}

Transesterification reactions were performed in a $500 \mathrm{~mL}$ threeneck flask equipped with a thermometer, a sampling port and a reflux condenser. The condenser was connected to a vacuum line equipped with a relief valve, accumulator and vacuum trap. The reactor was filled with a known amount of TMP at a molar ratio of CMEs to TMP of $3.9: 1$, our now day study. The reactant was then heated and stirred with a magnetic stirrer in the temperature-controlled oil bath while under vacuum until the TMP melted at about $60{ }^{\circ} \mathrm{C}$. Then the CMEs was added to a flask, and the mixture was heated to the operating temperature of $110{ }^{\circ} \mathrm{C}$ under vacuum pressure of 1-2 mbar. The calcium oxide catalyst was then added at a fixed $3 \% \mathrm{w} / \mathrm{w}$ based on the total mass of reactants. The vacuum was applied gradually to avoid spill over of the reaction materials. Samples were taken at specific time intervals, where each sample was collected in a small, capped vial and was immediately refrigerated at $2{ }^{\circ} \mathrm{C}$ for products analysis. Finally, the reaction mixture was cooled to room temperature and vacuum filtered to remove the catalyst and solid materials formed during the reaction.

\subsection{Analysis}

Analysis of TMP esters was performed on a HP 5890II gas chromatograph fitted with a capillary inlet system and flame ionization detector. The capillary column, HP INNOWAX, was $30 \mathrm{~m}$ long, with $0.25 \mathrm{~mm}$ i.d. and $0.25 \mu \mathrm{m}$ film thickness. A split injection system 20:1 was used with helium carrier gas at head pressure of 0.6 atm. The column temperature was held at $50{ }^{\circ} \mathrm{C}$ throughout the entire $6 \mathrm{~min}$ run. Temperature programming was initiated at $50{ }^{\circ} \mathrm{C}$ at the rate of $10{ }^{\circ} \mathrm{C}$ $\mathrm{min}^{-1}$ to reach a temperature of $250{ }^{\circ} \mathrm{C}$. The inlet 
temperature was $250{ }^{\circ} \mathrm{C}$ and the detector temperature was $280{ }^{\circ} \mathrm{C}$. $1.0 \mathrm{~mL}$ of each prepared sample was automatically injected into the GC system.

\subsection{Viscosity}

Viscosity measurements were made at 40 and 100 ${ }^{0} \mathrm{C}$ using Cannon Fenske viscometer tubes in a Cannon Constant Temperature Viscosity Bath (Cannon Instrument Co., State College, PA). Viscosity and the viscosity index were calculated using ASTM methods D445 and D2270, respectively. All viscosity measurements were made in triplicate, and the average value was reported.

\subsection{Pour point}

Pour points were determined by ASTM method D97 with an accuracy of $\pm 3{ }^{\circ} \mathrm{C}$ using Automatic Pour Point Tester manufactured by Dott. Gianni Scavini \& Co., Italy. All the runs were carried out in duplicate. Sample temperature was measured in $3{ }^{\circ} \mathrm{C}$ increments at the top of the sample until it stopped pouring.

\subsection{Flash point}

Flash point of the products was determined using Koehler Inc. apparatus as per ASTM D 93 method. The lowest temperature at which application of the test flame causes the vapour above the surface of the liquid to ignite is taken as the flash point of the product at ambient barometric pressure.

\section{Result and Discussion}

\subsection{Effect of Temperature}

The results show that the reaction temperature influences the formation of $\mathrm{ME}, \mathrm{DE}$ and TE. The formation of TE increases with the increase of reaction temperature but drops slightly at $150^{\circ} \mathrm{C}$ (Figure 2). CMEs content in the reaction mixture also decreases during the reaction as it being transformed into ME, DE and TE. High temperature can cause the vaporization of CMEs from the reaction mixture and thus, encouraging forward reaction to form TE (Yunus 2003a). Vaporized CMEs mixture and produce a reversible reaction [8]. The aim of the study is to focus on TE production as it has good high temperature properties compared to $\mathrm{ME}$ and DE. The production of TE is high at $150{ }^{\circ} \mathrm{C}$ with few $\mathrm{DE}(5.80 \%)$ and $\mathrm{ME}(0.40 \%)$ formation in the final product. Although ME formation records the lowest $(0.30 \%)$ at $130{ }^{\circ} \mathrm{C}$, and $\mathrm{DE}(2.02 \%)$ at $110^{\circ} \mathrm{C}$, both temperatures however record lower TE compare with when it was at $150{ }^{\circ} \mathrm{C}$.

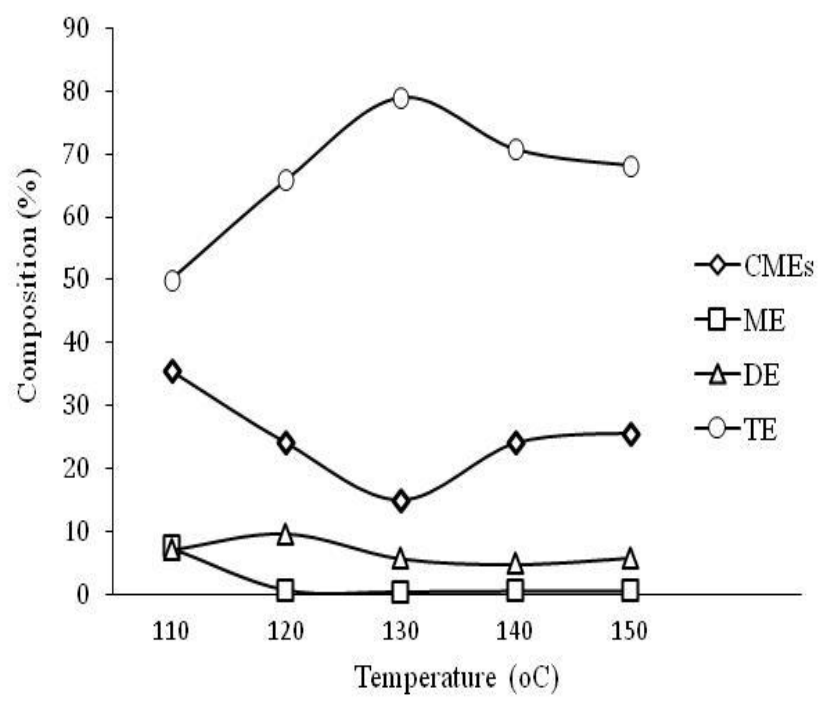

Fig. 2 Effect of temperature on transesterification of calophyllum methyl ester with TMP (TMP : CMEs = 1:3.9 ; catalyst $3 \% \mathrm{w} / \mathrm{w}, 5 \mathrm{~h}$ )

\subsection{Effect of Molar Ratio}

One of the methods to promote forward reaction (fig. 1) is by using excess amount of one of the reactan. Since calophyllum methyl ester are relatively cheaper compared to trimethylolpropane, the reaction was subjected to excess methyl ester. The stoikiometri molar ratio between the calophyllum methyl ester and trimethylolpropane is $3: 1$. This is to ensure that the reaction was unconstrained by the effectof excess reactant. The investigation on the effect of CMEs : TMP molar ratio to conversion to TMP esters was carried out at $130{ }^{\circ} \mathrm{C}$ in 5 hours and catalyst was maintained at $3 \%$ $\mathrm{w} / \mathrm{w}$ in all experiment. The effect of molar ratio of TMP : CMEs on product composition is shown in Figure 3. The results are summarized in figure 3 which show that there is no significant effect of increasing molar ratio on the conversion of TMP ester. Slightly higher percentage of TMP esters was obtained at molar ratio of $1: 3.7$ and 1 : 3.9. However, the difference was so small (70.40\% and $71.80 \%$ ) that no conclusion could be withdrawn from the study.

\subsection{Viscosity}

The biolubricant product obtained from calophyyllum methyl esters under the developed optimum synthesis conditions was evaluated for its lubrication properties. These properties were then compared with those of palm oil, canola (B. Napus) biodiesel-derived biolubricant, esterifed rapessed oil and ISO VG 46. Table 1 shows a comparison of the lubrication properties of both biolubricants with reference to ISO VG 46 specifications. Determination of kinematic viscosity is important from the point of view of the ability of a lubricant to efficiently lubricate contact surfaces. 
Citation: Widyawati,Y., Suryani, A., Romli,M. \& Sukardi (2014) Synthesis of Trimethylolpropane Esters of Calophyllum Methyl Esters : Effect of Temperature and Molar Ratio. Int. Journal of Renewable Energy Development, 3(3), 188-192. doi: 10.14710/ijred.3.3.188-192

$\mathrm{P}$ a g e | 191

Kinematic viscosities were determined at $40^{\circ} \mathrm{C}$ and $100^{\circ} \mathrm{C}$. Previous researchers reported kinematic viscosities at $40^{\circ} \mathrm{C}$ and $100^{\circ} \mathrm{C}$ of $52.40-10.20 \mathrm{cSt}$ for TMP esters of palm oil (E. gueneensis) (Yunus et al., 2003b).

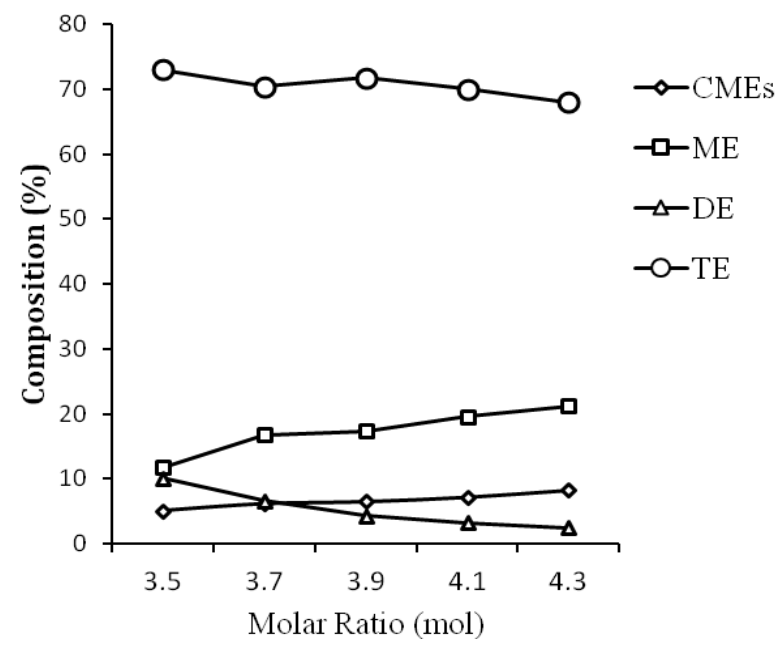

Figure 3 Effect of molar ratio on transesterification of calophyllum methyl ester with TMP (catalyst $3 \% \mathrm{w} / \mathrm{w}, 130{ }^{\circ} \mathrm{C}$, $5 h)$

Similarly reported are kinematic viscosities at $40{ }^{\circ} \mathrm{C}$ and $100{ }^{\circ} \mathrm{C}$ of $40.5 \mathrm{cSt}-7.8 \mathrm{cSt}$ for TMP ester canola oil (B. Napus) (Sripada 2013), respectively. Calophyyllum methyl esters-derived biolubricant on the other hand was found to have kinematic viscosities of $56.40 \mathrm{cSt}$ and $8.8 \mathrm{cSt}$ at $40{ }^{\circ} \mathrm{C}$ and $100{ }^{\circ} \mathrm{C}$ respectively. ISO VG 46 is a standard specification for light gear oil lubricant. This specification was used as a reference for comparison. All the tribological properties of biolubricants were found to meet these specifications, except for the viscosity of calophyllum methyl esters-derived biolubricant, kinematic viscosities of $56.40 \mathrm{cSt}$ at $40{ }^{\circ} \mathrm{C}$, which was a bit higher than the recommended value of 41.4 cSt. This was due to the high monounsaturation and polyunsaturation in calophylllum methyl ester, which effectively resulted in higher viscosity. The viscosity of fluids tends to decrease as temperature is increased. VI quantifies the extent of change in the viscosity of lubricant with a change in temperature. Higher the VI, lesser is the change in viscosity of the lubricant with a change in temperature. A previous study reported the synthesis of TMP esters of palm oil ( $E$. gueneensis) were found to exhibit high VI values of 167187 (Yunus et al. 2003b). A VI value of 204 was obtained for polyol esters of canola oil (Sripada et al. 2013). TMP esters of C5-C18 fatty acids were observed to have VI values of 80-208 (Ákerman et al. 2011). Using the kinematic viscosity values at $40{ }^{\circ} \mathrm{C}$ and $100{ }^{\circ} \mathrm{C}$, viscosity indices for calophylllum methyl ester derived biolubricants were calculated. Calophyllum methyl ester derived biolubricant was found to have high VI value of 193.
Table 1

Properties of calophyllum biolubricant at various temperatures and comparison with other plant based biolubricants.

\begin{tabular}{|c|c|c|c|c|c|c|c|c|c|}
\hline \multirow{2}{*}{$\begin{array}{c}\text { Detail } \\
\text { Temperatur }\left({ }^{\circ} \mathrm{C}\right)\end{array}$} & \multicolumn{5}{|c|}{ Calophyllum oil biolubricant } & \multirow{2}{*}{$\begin{array}{c}\text { Palm oil } \\
\text { biolubricant }{ }^{\text {a }}\end{array}$} & \multirow{2}{*}{$\begin{array}{l}\text { Canola oil } \\
\text { biolubricant }{ }^{b}\end{array}$} & \multirow{2}{*}{$\begin{array}{c}\text { Esterified } \\
\text { rapeseed oil c }\end{array}$} & \multirow[t]{2}{*}{ ISO VG 46d } \\
\hline & 110 & 120 & 130 & 140 & 150 & & & & \\
\hline \multicolumn{10}{|l|}{ Viscosity } \\
\hline $40^{\circ} \mathrm{C}$ & 35.28 & 54.43 & 56.40 & 56.87 & 56.93 & 52.40 & 40.5 & 35.34 & $>41.4$ \\
\hline $100^{\circ} \mathrm{C}$ & 7.68 & 8.49 & 8.80 & 8.70 & 8.32 & 10.20 & 7.80 & 7.99 & $>4.1$ \\
\hline $\begin{array}{l}\text { Viscosity Index } \\
\text { (IV) }\end{array}$ & 190 & 192 & 193 & 188 & 184 & 186 & 204 & 209.2 & $>90$ \\
\hline Pour Point & -1 & -2 & -3 & -1 & -1 & .5 & .66 & -15.5 & -10 \\
\hline Flash Point & 222 & 214 & 212 & 214 & 213 & . & $\cdot$ & $\cdot$ & - \\
\hline
\end{tabular}

a Yunus et al. 2003 ; b Sripada et al. 2013 ; c Gryglewicz et al. 2003 ; d Comercial lubricant

\subsection{Pour Point}

Low-temperature fluidity is the most important property for a lubricant to perform in extremely cold environments typical during the harsh winters of Canada, especially in Saskatchewan. A measure of the pour point values determine the cold flow properties of a lubricant. Pour point is the lowest temperature at which movement of the liquid is observed. A lot of work has been reported on the development of TMP triesters derived from palm (E. gueneensis) oil methyl esters (Yunus et al. 2003). They synthesized TMP lubricants from palm kernel (E.gueneensis) oil methyl esters, which had high pour points between $+1^{\circ} \mathrm{C}$ and $-1^{\circ} \mathrm{C}$. In this work the pour point of the calophyllum metyl esters is $-3{ }^{\circ} \mathrm{C}$.

\subsection{Flash Point}

Flash point is used to determine the beginning of the lubricant will fire or flame arise while in the machine. The flash point of the calophyllum methyl ester is 212 ${ }^{0} \mathrm{C}$ indicating a low tendency to evaporation which fulfils one of the basic requirements of lubricants.

\section{Conclusion}

The transesterification of CMEs with TMP using calcium oxide as catalyst has successfully formed TMP esters with the percentage of TE (79\%). Results of reaction duration: 5 hours, temperature $130{ }^{\circ} \mathrm{C}$, molar ratio of CMEs: TMP is 3.9:1 and catalyst concentration: $3 \% \mathrm{w} / \mathrm{w}$ (based on weight of reactan) are sufficient for the transesterification of TMP esters as biolubricant base stocks. In addition, the pour point of the product was observed of $-3{ }^{0} \mathrm{C}$, flash point is $212{ }^{\circ} \mathrm{C}$ and kinematic viscosities of $56.40 \mathrm{cSt}$ and $8.8 \mathrm{cSt}$ at $40{ }^{\circ} \mathrm{C}$ and $100{ }^{\circ} \mathrm{C}$ that resulting calophyllum TMP esters has a high potential for the production of lubricants. 


\section{Acknowledgments}

The authors gratefully acknowledge to Directorate of Higher Education of Indonesia for the financial of Doctoral Research.

\section{References}

Castro, W., Perez, J.M., Erhan, S.Z., Caputo, F. (2006) A study of the oxidation and wear properties of vegetable oils: soybean oil without additives. J. Am. Oil Chem. Soc. 83, 47-52.

Doll, K.M., Sharma, B.K., Erhan, S.Z. (2007) Synthesis of branched methyl hydroxyl strearates including an ester from bio-based levulinic acid. Ind. Eng. Chem. Res. 46, 3513-3519.

Lathi, S.P. \& Mattiason, B. (2006) Green Approach for the Preparation of Biodegradable Lubricant Base Stock from Epoxidized Vegetable Oil. Journal of Applied Catalysis B: Environmental 69: 207-212.

Leung, D.Y.C., Wu, X., Leung, M.K.H. (2010) A review of biodiesel production usingcatalyzed transesterification. Appl. Energy 87, 1083-1095.

Gryglewicz, S., Piechocki, W., Gryglewicz, G. (2003) Preparation of polyol esters based on vegetable and animal fats. Bioresour. Technol. 87, 35-39.

Phani K. Sripada, Rajesh V. Sharma, Ajay K. Dalai. (2013) Comparative study of tribological properties oftrimethylolpropane-based biolubricants derived frommethyl oleate and canola biodiesel, Journal Industrial Crops and Products 50, 95- 103

Salimon J, N. Salih, E. Yousif (2010) Improvement of pour point and oxidative stability of synthetic ester basestocks for biolubricant applications, Arab. J. Chem. 5, 193-200.

Metzger, J.O. (2009) Fats and oils as renewable feedstock for chemistry. Eur. Lipid Sci. Technol. 111, 865-876.

Nagendramma, P., Kaul, S. (2012) Development of ecofriendly/biodegradable lubri-cants: an overview. Renew. Sustain. Energy Rev. 16, 764-774.

Uosukainen, E., Linko, Y.-Y., Lamsa, M., Tervakangas, T., Linko, P. (1998) Transesterifi-cation of trimethylolpropane and rapeseed oil methyl ester to environmentallyacceptable lubricants. J. Am. Oil Chem. Soc. 75, 1557-1563.

Willing A. (2001) Lubricants based on renewable resources - an environmentally compatible alternative to mineral oil products. Chemosphere ;43:89-98.

Robiah, Y., Fakhru'l-Razi, A., Ooi, T.L., Iyuke, S.E dan Idris, A. 2003a. Development of Optimum Synthesis Method for Transesterification of Palm Oil Methyl Esters and Trimethylolpropane to Environmentally Acceptable Palm OilBased Lubricant. Journal of Oil Palm Research 15 (2): 35-41.

Robiah, Y., Fakhru'l-Razi, A., Ooi, T.L., Iyuke, S.E dan Idris, A. 2003b. Preparation and Characterization of Trimethylolpropane Esters from Palm Kernel Methyl Esters. Journal of Oil Palm Research 15 (2): $42-49$ 